DOI https://doi.org/10.18551/rjoas.2018-02.01

\title{
THE VIEWPOINT OF STAKEHOLDERS ON THE CAUSES OF FOREST AND LAND FIRES IN RIAU PROVINCE, INDONESIA
}

\author{
Badri M.* \\ Faculty of Da'wah and Communication, Sultan Syarif Kasim State Islamic University, \\ Pekanbaru, Indonesia \\ Lubis D.P., Susanto D. \\ Faculty of Human Ecology, Bogor Agricultural University, Bogor, Indonesia
}

Suharjito D.

Faculty of Forestry, Bogor Agricultural University, Bogor, Indonesia

*E-mail: muhammad.badri@uin-suska.ac.id

\begin{abstract}
Riau Province is one of the prone areas of forest and land fires in Indonesia. Fires began to grow since the 1980s as deforestation and the clearing of palm oil plantations occured. The peak of a major fire was happened before the study was taken from 2014 to 2015 and caused a smoke haze for months. This study aims to determine the factors causing forest and land fires in Riau in the viewpoint of stakeholders. The research is conducted by using qualitative methods by exploring stakeholder viewpoint through semi-structured interviews on actors representing government, companies, research institutions, NGOs, mass media and community groups. The results show that all stakeholders have the same viewpoint regarding the cause of human-fire perpetrators. Burning is largely done intentionally in open access areas, disputes, concessions, corporate land, and community lands. Fires continue to occur due to lack of oversight by authorities, massive peatland clearance, deforestation, increased permission for forest or land management for political costs, land disputes, human negligence and weak law enforcement.
\end{abstract}

\section{KEY WORDS}

Forest and land fires, smoke disaster, Riau fires, viewpoint, stakeholders.

Indonesia has a long history of forest and land fires. Forest fires in Indonesia have occurred since the 1970s. The first was caused by intentional factors such as local people did clear the fields with forest burning, campfire hunters, to camping people in the forest. The most severe fires occurred in 1972 and 1976 due to forest fires. The site of the fire was mostly located in Java, Borneo and parts of Sumatra, causing most of Sumatra and surrounding islands covered by smog making the visibility distance of less than 100 meters. In October 1972 almost all of Sumatra and the islands of the east coast except the northern and southern edges, and a small portion of the western coast and parts of West Kalimantan and Malaysia were covered in smog (Kompas, 2016).

Non-governmental organization (NGO) monitors the oil palm plantation industry, mention forest and land fires in Riau also occurred in 1982/1983 with an area of 3,600,000 hectares (ha), in 1987 with an area of 66,000 ha, in 1991 with an area of 500,000 ha, in 1994 with an area of $5,110 \mathrm{Ha}$, and 1997/1998 with an area of 10,000,000 ha. The case during the 1980-1990s period had not been responded in the form of specific and clear law policies. At that time, the government had not yet seen forest fires as a problem that needed to be responded to through regulatory significance. In practice, the handling of forest fires was performed by the Ministry of Forestry and land fires by the Ministry of Environment (Sawit Watch, 2014).

Land and forest fires in Riau continued that the expansion of oil palm plantations land by plantation corporations happened from the 1980s. Fires in Riau had been in the spotlight 
since the 1997-1998 incident due to the widespread fires in Indonesia as a result of the long drought. By early 1998, nearly 10 million ha had been affected by fires causing a range of damages estimated at nearly 10 billion dollars. Smoke from the fires caused most of Southeast Asia to fog up to several months (FWI, 2001). The widespread to this incident has been attention issue in 1999 when the smog reached Malaysia and Singapore. In 2013, smoke haze occurred twice a year, a different phenomenon than in previous years which only occured once a year (Tampui, 2014). In the event of 2014 the loss and deprivation due to Karhutla Riau reached 935 million US dollars (World Bank, 2014). In 2015, the total loss was Rp 221 trillion (World Bank, 2015).

Based on this background, the formulation of this research problem is how stakeholder viewpoint is about the causes of forest and land fires in Riau Province. This study aims to determine the factors causing forest and land fires in Riau in the viewpoint of stakeholders. Literally, viewpoint is the fruit of thought or approximation of a thing (in Indonesian dictionary). The viewpoints are active responses to stimuli, responses are made through personal interpretations that are derived and form an image. Each viewpoint reflects a complex organization consisting of three components of trust, value, and expectation (Nimmo, 2006). Berger \& Luckmann (1991) in The Social Construction of Reality: A Treatise in the Sociology of Knowledge reveals that the same view expressed by many people that has a greater weight than one. The subjective crystallization of results from these various definitions of reality will determine the tendency of one's reaction to a problem.

\section{METHODS OF RESEARCH}

The study was conducted in Riau Province from December 2016 to August 2017. The deliberation of selecting the site, it is because Riau is a prone area of forest and land fires in Indonesia. Research is designed with a qualitative approach to gain an in-depth understanding of a problem (Denzin \& Lincoln, 2005). The viewpoints about the causes of fires are extracted through semi-structured interviews against forest and land fire stakeholders consisting of government representatives, companies, research institutes, NGOs, mass media and community groups. Researchers also extract the secondary data from government agencies, research reports, NGOs and the mass media. The data collected then is processed and analyzed using interactive data model analysis with three steps: data condensation, data presentation and conclusion / verification (Miles et al., 2014).

\section{RESULTS AND DISCUSSION}

Forest and land fires are generally affected by two main factors, namely climate conditions and human activities in forest and land management. The cause of fire in Indonesia is almost entirely derived from human activities (99\%), whether intentionally or not. Land conversion activities accounted for $34 \%$, wild inflammation for $25 \%$, agriculture for $17 \%$, social jealousies for $14 \%$, and transmigration projects for $8 \%$. Another factor causing the greatness of forest and land fires is the source of energy in the form of timber, felling, coal deposits, and peat (BNPB 2013). In addition, massive deforestation in Riau since the 1980s has been the cause of frequent fires. According to data from the Palm Oil Agribusiness Strategic Policy Institute (PASPI), based on Indonesia's Vegetation Map, in 1950 forest area in Riau reached 8.7 million hectares, in 1985 it shrank to 5.07 million ha, and 2014 it remained to 2.5 million ha. Thus, since 1950-2014, deforestation occurred in Riau reached 6.2 million ha. Deforestation in Riau prior to 1985 occurred as a result of logging activities that caused economic and ecological degradation, leaving critical, backward, poor and dead districts (PASPI, 2017).

The process of deforestation and degradation of natural forests in Riau is very fast. For 24 years (1982-2005) Riau Province has lost of natural forest cover of 3.7 million ha. In 1982, the natural forest cover in Riau still covered $78 \%(6,415,655$ ha) of Riau's land area $8,225,199$ ha $(8,265,556.15$ ha). Until 2005 , the remaining natural forest was only $2,743,198$ ha (33\% of Riau's land area). During that period, Riau Province was regularly about 160,000 
ha / year of natural forests annually and during the 2004-2005 period the lost natural forests reached 200 thousand ha. The proliferation of forestry industry in Riau has become one of the causes of natural forest degradation increasingly uncontrolled. Until 2000, the number of forestry industries operating in Riau reached 312 units consisting of 10 units of plywood industry, sawmill 270 units, molding 27, chip mill 3 units and 2 units of pulp and paper industry (Jikalahari, 2014).

The data of KLHK (2016a) and KLHK (2016b) indicate an increase in the number of hotspots and fire area in Riau with its peak in 2014. Number of hotspots were in 2011 (6,849), 2012 (7,826), 2013 (15,089), $2014(22,588)$ and 2015 ( 7.262). Then the land burnt in Riau was in 2011 (74.50 ha), 2012 (1,060 ha), 2013 (1,077.50 ha), 2014 (1,077.50 ha) and 2015 (6,301.10 ha). The data, when paired with deforestation data in Riau (Jikalahari, 2014), is increasing annually, there is a significant relationship between forest destruction and the potential for fire (Figure 1).

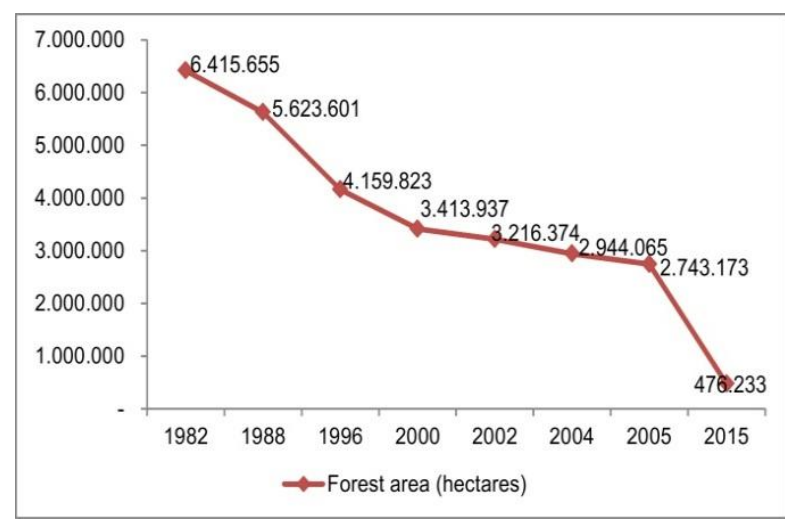

(a)

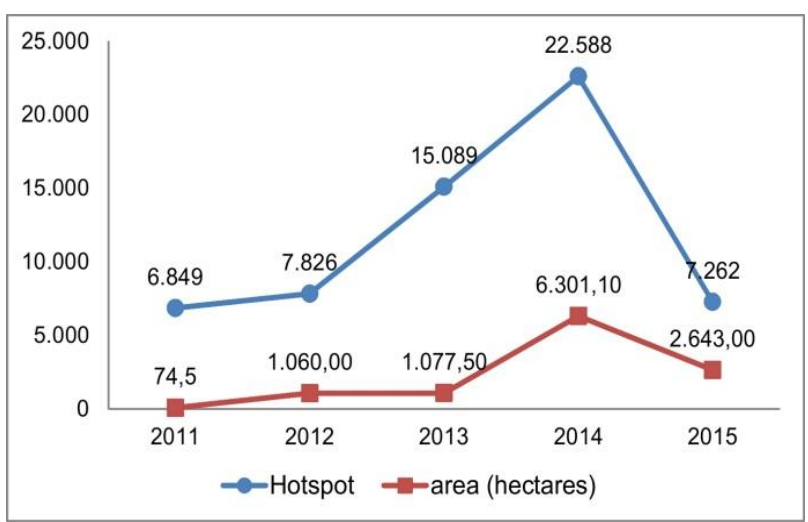

(b)

Figure 1 - Deforestation in Riau (a) and hotspot data and fire area in Riau in 2011-2015 (b).

Deforestation in Riau causing economic and ecological degradation is overcome by the clearing of oil palm plantations. In this case, it comes to the construction of social reality to the problem of fire in Riau. Logged-over land used for logging can not be directly planted with oil palm due to shrubs and forests. The process of clearing land of the plantations breaking in the 1980s and 1990s still legalized the burning and even became the standard operation of the plantation companies. In that period researchers looked at forest and land fires associated with deforestation processes for logging and oil palm plantations. The process of plantation land clearing is generally executed by cutting down the remaining forest for the plantation area, until summer comes then it is burnt. After the large wood is burnt and then it hacks and burns until it is ready to plant the oil palm. The impact of burning on minerals at that time is not as severe as in peatland because after the heavy fires occurred, usually it will come to heavy rain. The impact of smoke is also only experienced by people around the burnt area.

In the absence of controlled firing patterns and adequate law enforcement, fires become uncontrollable, driven by drought and exacerbated by the influence of El Nino. Moreover, burning has long been a device of agriculture in Indonesia. Unofficially, the burning process also plays an important role in land clearing. So while many are harmed by the widespread of fires and haze, a number of parties have benefited enormously. Peatland drainage and conversion, driven primarily by palm oil production, it contributes to the increased smoke haze intensity of fires. Approximately 33 percent of the total burned land was peatland causing hazardous smoke (World Bank, 2016).

Research result of Permana \& Kurniawan (2001) in Petapahan (Riau) explained that clearing of plantation forest area and oil palm plantation became one of the factors causing fire in this location. Most of the companies cleared and prepared the land using fire, which this system was performed before 1998. At that time, the government had not been incentive 
to sanction to the perpetrators of forest and land burning in Indonesia. Although the government had banned the use of fires in the preparation of plantation land, it was less effective, as seen from the large number of firms operated fire in their land preparation activities. The ineffectiveness of the policy was mainly as the use of fire was economically very cheap and easy.

Research of Purnomo et al. (2017) in three districts in Riau also found that in addition to demographic or population factors, almost all research sites were linked to illegal logging activities in the past. The forest fire chain started from land claims, slash and clearing, burning, and planting oil palm or acacia. Land claims at the study sites indicated that they had appeared since 2004 and in some places also existed on several years earlier. Land claims involved local communities as well as those acting on behalf of local communities. The perpetrators linked to illegal logging activities were the key actors who knew the 'uninvest' areas or the abandoned 'owners' (open access). The area was finally contested and became a land claim event that later led to the sale and bargaining of land.

Research institutes that frequently conducts research on forest and land fires in Riau is the Riau University Disaster Studies Center (PSB) and the Center for International Forestry Research (CIFOR). In the viewpoint of the research institute, fires in Riau are complex, but the most dominant is the massive peatland clearance that is out of control. The absence of a fire control system causes a continuous fire incident to date. Before 1997, the companies and communities in Riau cleared the land by burning, but at that time the location was in the mineral land area. Forest fires and mineral land is the land where the wood or biomass is burnt down then the fire immediately goes out. Once the mineral land is depleted, the expansion of the land switchs to the peat. Peatlands are different when it is burnt, especially during the dry season, even though the biomass is exhausted, peat soil remains burnt. The burns are identified as "invisible hands" playing behind the scenes so they are not reached. The main motive is due to economic factors for the clearing of oil palm plantations.

The government has the viewpoint that the most important factor to the occurrence of fire is human behavior. There are four sources of fire: fire, fuel, weather, and human behavior. The greatest cause of fire is human behavior. In addition, the condition of peat soil in Riau causes the fire to become more severe. Fires on community land are generally only existed in small spots. In addition, fires continues to occur due to lack of supervision. Actually, the perpetrators of burning know about the prohibition of burning forest and land. But the burning continues as the perpetrator has an interest, by burning the land, the costs are cheap and provide some benefits. Usually the perpetrator performs the burning after the patrol officers move away from the location. Seeing that condition, the disaster management authority in Riau wants a better monitoring and supervision system, especially in areas that are difficult to reach by patrollers.

Sawit Watch (2014) noted several aspects that perpetuate forest and land fires, among them: (1) releasing of licenses for oil palm plantations and other large-scale enterprises in peat ecosystems; (2) Non-optimal enforcement and legal supervision over the perpetrators of arson; (3) Responsible disposal for who was the perpetrator of forest and land burning as a result of legal loopholes; (4) expansion of oil palm plantations; (5) The existence of inequality of land tenure in areas of forest and land fires; (6) Sustainable palm oil certification did not positively correlate directly with the incidence of land fires in oil palm plantation concessions.

The phenomenon of forest and land fires had been the concern of NGO Jikalahari since its establishment in 2002. This NGO explains that in the last 20 years the hotspot map shows that most of them are located in areas where there are concessions or areas of forestry and palm oil companies. In the last 10 years there has been frequent fires in the company area as well as in areas infiltrated by encroachers and broker (individual capital owners) in conservation areas, national parks, wildlife reserves and protected forests. Most fires occur within forest areas, especially conservation areas and production forests. Then outside the forest area, the fires usually appears in oil palm plantations. Fires in forest areas and outside of the forest dominantly arise to forest areas occured in the peatlands. Yayasan Mitra Insani (YMI), often conducting community empowerment activities in resource management and fire prevention, explains the rampant illegal logging after regional 
autonomy causing high deforestation as a trigger of fire. The biggest cases of deforestation are usually in post general election and regional head elections (called Pilkada) as they relate to political costs. Increased deforestation occurs due to increased permissions for forest or land management for the clearing of oil palm plantations. Once permission is obtained, the owner of the concession then performs land clearing by burning.

Every fires in Riau companies are often accused of being perpetrators, especially companies engage in forestry and plantation sectors. However the company denies it. In their view, the fire actually compromises the company because it inhibits the production process. The forestry company describes having 'no burn policy' and sustainable forest management policy supervised by government authorities. Oil palm companies has certified Indonesian Sustainable Palm Oil (ISPO) and Roundtable on Sustainable Palm Oil (RSPO) certification programs, which one of the conditions is not allowed to burn. The company viewed the fire is caused by human activities, whether intentionally or not. Unintentional factors are, among others, the fire of hunters and anglers, or tosses of cigarettes. On the other hand, the deliberate factor is sabotaging on land claimed to the company owned in a state of disputation with a particular group. It also happens in the open acces around the company area.

Fires in rural areas according to the view point of the MPA (Masyarakat Peduli Api The Fire Care Community) are caused by small-scale burning firewood to clean the shrubs and weeds. Problems arise when the farmer goes away and forget to extinguish the fire. As a result, within a few hours, fires are more severe if they occured in peatlands, because even though the surface has gone out, but the fire in the ground is still burning. In addition, rural fires are common in open access areas around the village. Fires in these areas are difficult to be quenched because usually they are empty land and scrub with a very difficult location to access. Open access land is a former concession land and the abandoned past government program land and becoming into a dam field or scrub.

Mass media as a device of communication constructs the cause of forest and land fires in Riau. The mass media with editorial policy on environmental issues is Green Radio (GR). GR explains that the fire is deliberately performed by irresponsible parties. The perpetrators are the company or people who are paid by the company, as well as unscrupulous people. Burning is planned for business purposes, whether buying and selling land or plantation opening. Media investigations find most fires occurred in open access and concession areas, as well as a small portion of community land. Another factor that causes longevity of fires is the weakness of law enforcement as without good law enforcement, fires are never completed.

Table 1 - Social construction related to the cause of forest and land fires in Riau

\begin{tabular}{|c|l|l|}
\hline \multirow{2}{*}{ Stakeholders } & \multicolumn{2}{|c|}{ The Viewpoint Construction } \\
\cline { 2 - 3 } & Actors & \multicolumn{1}{c|}{ The Continue Causes of Fire } \\
\hline $\begin{array}{c}\text { Government } \\
\text { Researcher } \\
\text { organization }\end{array}$ & Human & Lack of supervision on the burnt prone areas \\
\hline NGOs & Human & $\begin{array}{l}\text { Massive peatland clearance } \\
\text { The rise of deforestation due to increased forest or land management licenses }\end{array}$ \\
\hline Company & Human & $\begin{array}{l}\text { Sabotage on the land belonging to the company in dispute and open access land } \\
\text { around the company area. }\end{array}$ \\
\hline MPA & Human & The negligence of local people using fire for land clearing later not to extinguish it. \\
\hline Mass media & Human & Weak law enforcement \\
\hline
\end{tabular}

From the above explanation, it can be taken that stakeholders has different construction viewpoints related to the causes of forest and land fires continuing in Riau, but all point to the same actors that was human. No fires in Riau caused by natural factors such as lightning and volcanic eruptions. Fires continues to occur due to lack of oversight by authorities, massive peatland clearance, deforestation, increased permission for forest or land management for political costs, land disputes, human negligence and weak law enforcement. Burning is largely performed intentionally in open access areas, disputes, 
concessions, corporate land, and community lands. Combustion motives are vary, generally it is for plantation opening or raising the sale price of the land. Previous research has also supported these findings, for example, fires caused by some people assume that slash and burner systems are an easy, cheap and effective way of preparing land (Permana \& Kurniawan, 2001). In terms of economy, land prices will soar if it is sold in 'ready to plant' where the land has been cleared and burnt (Purnomo et al., 2017).

\section{CONCLUSION}

Forest and land fires in Riau is a non-natural disaster phenomenon causing smog. Fires impact the environmental damage, economic losses, health problems and social activity disruptions. Forest and land fires in Riau have been going on for decades. According to stakeholder viewpoint constructions, fire actors are either individual or group of people, who burn intentionally. The viewpoints about motives are vary however they all refer to economic factors. The government has been for decades responded to this problem through post-fire prevention with the blackout. Though prevention activities are a better opportunity than blackouts with big cost. Integrated efforts have only been made by the government since the great fire incident of 2014 to 2015. Seeing human as the main cause, the prevention should involve human behavior intervention through communication, socialization, education and law enforcement. The actors that need to be involved include all stakeholders from government, companies, research institutions, NGOs, the mass media, to the community.

\section{REFERENCES}

1. Berger, P.L. \& Luckmann, T. (1991). The Social Construction of Reality: A Treatise in the Sociology of Knowledge. London: Penguin Books

2. BNPB [Indonesian National Board for Disaster Management]. (2013). Rencana Kontinjensi Nasional Menghadapi Ancaman Bencana Asap Akibat Kebakaran Hutan dan Lahan. Jakarta: BNPB

3. Denzin, N.K. \& Lincoln, Y.S. (2005). The SAGE Handbook of Qualitative Research. Third Edition. California: Sage Publications.

4. FWI [Forest Watch Indonesia]. (2001). Keadaan Hutan Indonesia. Bogor: Forest Watch Indonesia-Global Forest Watch

5. Jikalahari [Riau Forest Rescue Network]. (2014). Fakta Kritis Analisa Tata Kelola Kehutanan di Provinsi Riau. [2017, December 2] Retrieved from http://jikalahari.or.id/wpcontent/uploads/2016/03/FAKTA-KRITIS-ANALISIS.pdf

6. KLHK [Ministry of Environment and Forestry].(2016a). SiPongi: Karhutla Monitoring Sistem. [2016, May 29]. Retrieved from http://sipongi.menlhk.go.id/home/karhutla_ monitoring_system

7. KLHK.(2016b). SiPongi: Karhutla Monitoring Sistem. [2016, May 29]. Retrieved from http://sipongi.menlhk.go.id/hotspot/luas_kebakaran

8. Kompas. (2016). Kebakaran Hutan di Era 1970-an: Dari Cara Berladang sampai Api Unggun. [2017, September 10] Retrieved from http://cdn.assets.print.kompas.com/baca/iptek/ lingkungan/2016/08/31/Kebakaran-Hutandi-Era-1970-an-Dari-Cara-Berladang

9. Miles, M.B., Huberman, M. \& Saldana, J. (2014). Qualitative Data Analysis: a Methods Sourcebook. Third edition. California: Sage Publications.

10. Nimmo, D. (2006). Komunikasi Politik: Khalayak dan Efek. Bandung: Remaja Rosdakarya.

11. PASPI [Palm Oil Agribusiness Strategic Policy Institute]. (2017). Proses Reforestasi dan Perbaikan Ekologi Melalui Perkebunan Sawit di Provinsi Riau. Monitor 3 (8): 689-696

12. Permana, R.P. \& Kurniawan, I. (2001). Akar Penyebab dan Dampak Kebakaran Hutan dan Lahan di Sumatera. Suatu Tinjauan terhadap Perubahan Penggunaan Lahan dan Aktivitas Penyiapan Lahan untuk Hutan Tanaman Industri dan Perkebunan. Studi Kasus: 
Petapahan, Propinsi Riau. In Suyanto et al. (Eds). Prosiding Seminar Kebijakan Pengelolaan Sumberdaya Alam dan Aktivitas Sosial Ekonomi dalam Kaitannya Dengan Penyebab dan Dampak Kebakaran Hutan dan Lahan di Sumatera. Bogor: ICRAFCIFOR.

13. Purnomo, H., Shantiko, B., Sitorus, S., Gunawan, H., Achdiawana, R., Kartodihardjo, H. \& Dewayani, A. A. (2017). Fire economy and actor network of forest and land fires in Indonesia. Forest Policy and Economics 78 (2017): 21-31. Doi: 10.1016/j.forpol.2017.01.001

14. Sawit Watch. (2014). Kebakaran Hutan dan Lahan, Siapa yang Melanggengkan? [2017, September 10] Retrieved from http://sawitwatch.or.id/2014/11/kebakaran-hutan-danlahan-siapa-yang-melanggengkan/

15. Tampui. (2014). 5 Fakta Kebakaran Hutan di Riau. Buletin Tampui Edisi 3 Tahun 1, 2014.

16. World Bank. (2014). Perkembangan Triwulanan Perekonomian Indonesia. Jakarta: The World Bank.

17. World Bank. (2015). Perkembangan Triwulanan Perekonomian Indonesia: Reformasi di Tengah Ketidakpastian. Jakarta: The World Bank.

18. World Bank. (2016). Kerugian dari Kebakaran Hutan. Analisa Dampak Ekonomi dari Krisis Kebakaran tahun 2015. Jakarta: The World Bank. 